\title{
Higher Cereal and Legume Yields Using Ca-bentonite on Sandy Soils in the Dry Eastern Uganda: Increased Productivity versus Profitability
}

\author{
Semalulu O. ${ }^{1, *}$, P. Elobu ${ }^{2}$, S. Namazzi ${ }^{2}$, S. Kyebogola ${ }^{3}$, D.N. Mubiru ${ }^{1}$ \\ ${ }^{1}$ National Agricultural Research Laboratories (NARL), Uganda \\ ${ }^{2}$ National Semi-Arid Resources Research Institute (NaSARRI), Uganda \\ ${ }^{3}$ College of Agricultural and Environmental Sciences, Makerere University, Uganda \\ *Corresponding Author: o.semalulu@gmail.com
}

Copyright $\subseteq 2017$ by authors, all rights reserved. Authors agree that this article remains permanently open access under the terms of the Creative Commons Attribution License 4.0 International License

\begin{abstract}
Moisture stress grossly limits crop yields in sub-Saharan Africa. Ca-bentonite holds and avails water for plant uptake. However, despite its availability and increasing droughts in Uganda, its use is limited, partly due to inadequate empirical evidence about its benefits. This 3 -season on-farm study assessed the benefits accruing from Ca-bentonite use. Crops included: maize (Longe 10H), finger millet (Seremi-2), sorghum (SESO-3), green-grams (Mauritius) and groundnuts (Serenut 6). Treatments were: Ca-bentonite (2.5 $\mathrm{t} \mathrm{ha}^{-1}$ ), Ca-bentonite combined with manure (FYM) and/or phosphate (DAP/SSP), replicated five times in CR design. Ca-bentonite $\left(2.5 \mathrm{t} \mathrm{ha}^{-1}\right)$ increased the grain yields of maize, millet, sorghum, green-grams and groundnuts by $11,20,14,17$ and $5 \%$ above the control. Bentonite combined with DAP/SSP and/or FYM increased maize, finger millet, sorghum, green-grams and groundnuts yields by $14-82 \%, 22-42 \%, 23-42 \%, 32-42 \%$ and $4-26 \%$, respectively. Higher grain yields were partly attributed to increased soil moisture following bentonite application. Compared to other crops, bentonite was more profitable when used on the higher priced groundnuts. Considering the high bentonite cost, application on high value crops, blending with other materials and policy support are recommended, to make this locally available resource economically viable for smallholder farmers, thereby help them cope better with increasing droughts.
\end{abstract}

Keywords Cattle Corridor, Climate Change Adaptation, Moisture Stress, Profitability, Soil Management

\section{Introduction}

Land degradation is a serious problem affecting agricultural productivity in Sub Saharan Africa (SSA). Rain-fed agriculture contributes over $95 \%$ of farmed land in the region (IWMI). However, recent studies indicate that droughts have become more frequent, intense and widespread in SSA during the last 50 years [1]. The cattle corridor covering over a third of the land area in Uganda and receives 500 to $900 \mathrm{~mm}$ of rainfall, is among the most degraded. The area is characterized by sandy soils with low nutrient and organic matter contents. In addition the low water holding capacity of sandy soils makes them generally fragile with low agricultural production [2]. In such soils, productivity declines rapidly due to loss of soil organic matter, decline in soil fertility, and consequently, increased land degradation. This is aggravated by the high temperatures, soil erosion, and nutrient leaching in tropical environments. These challenges collectively threaten the food security in the area.

In order to facilitate agricultural production on these fragile sandy soils, significant amounts of organic or inorganic fertilizers are required to maintain economic yields [3]. Under warm/hot temperatures of the tropics however, organic matter decomposes rapidly, and because of this, the amount required to maintain adequate levels of cation exchange capacity (CEC) is beyond the means of the average farmer [4]. In addition, the inherent low CEC of these soils limits their ability to retain nutrients such as $\mathrm{Ca}^{2+}, \mathrm{Mg}^{2+}$ and $\mathrm{K}^{+}$. Furthermore, use of inorganic fertilizer is often beyond the means of resource poor farmers and has the potential negative impact on the environment due significant leaching losses associated with the high hydraulic conductivity of light textured sandy soils. Under these conditions, addition of materials with high nutrient and moisture retention capacity such as bentonite could be a possible solution.

Bentonite is a 2:1 clay mineral known to hold water and avail it for plant uptake. It is mined in Hoima district, western Uganda. However, despite its availability and reported increase in droughts, its use in SSA and Uganda in particular, is limited. This may be due to inadequate empirical evidence 
about its benefits, limited availability to farmers in rural areas due to poor distribution, or in areas where it is available it may not be affordable due to high cost.

In the light textured soils of Western Australia where plants commonly experience moisture stress during the drier seasons, bentonite treatments up to $100 \mathrm{t} \mathrm{ha}^{-1}$ significantly improved the field capacity and plant available water (PAW) content [3]. This enhanced the growth and yield of forage sorghum. The field capacity and PAW consistently increased with increasing rates of bentonite added. Similar results were reported in Thailand [5, 6]. Furthermore, bentonite has been reported to improve the $\mathrm{pH}, \mathrm{CEC}$, nutrient retention and availability, improve fertiliser use efficiency and consequently, enhance agricultural productivity [3, 4]. Suzuki et al. [5] have shown that not only is the plant available water content increased with the application of bentonite but also the stability of aggregates. According to Manue et al. [7], bentonite applied to an acid soil, increased the $\mathrm{pH}, \mathrm{N}, \mathrm{K}$, and $\mathrm{P}$ contents. Biomass production for Lolium multiflorum increased as the dose of bentonite increased up to $5 \mathrm{~g} \mathrm{~kg}^{-1}$, but decreased at larger doses (possibly as a result of falling potassium/magnesium ratio and increasing electrical conductivity). Therefore, the objective of the study was to assess the extent of benefits accruing from Ca-bentonite use on sandy soils in the drier cattle corridor areas of Uganda.

\section{Materials and Methods}

\subsection{Characteristics of the Study Sites}

The experiment was conducted in Ngora and Katakwi districts, in Eastern Uganda. Both districts lie within the cattle corridor area of Uganda, characterized by slightly lower rainfall compared to other parts of the country. The area receives 600 to $900 \mathrm{~mm}$ average rainfall, bimodally distributed. The main season runs from March to May with peak in April and second season from August to November with a peak in October. Main dry seasons are December to February and June to July. Temperature ranges from 15 to $32.5^{\circ} \mathrm{C}[8]$.

\subsection{Field Procedures}

On-farm experiments were conducted during March to July 2015, August to December 2015 and March to July 2016. Five crops commonly grown in the area were tested, and included: maize (Longe 10H), sorghum (SESO-3), finger millet (Seremi-2), green-gram (Mauritius) and groundnuts (Serenut-6). Six fertilizer treatments were applied. For cereals, the treatments included: a control (nothing applied), bentonite at $2.5 \mathrm{t} \mathrm{ha}^{-1}$, bentonite $\left(1.25 \mathrm{t} \mathrm{ha}^{-1}\right)+$ diammonium phosphate (DAP, $\left.62.5 \mathrm{~kg} \mathrm{ha}^{-1}\right)$, bentonite $\left(2.5 \mathrm{tha}^{-1}\right)+\mathrm{FYM}$ $\left(2.5 \mathrm{t} \mathrm{ha}^{-1}\right)$, bentonite $\left(1.25 \mathrm{t} \mathrm{ha}^{-1}\right)+\operatorname{DAP}\left(62.5 \mathrm{~kg} \mathrm{ha}^{-1}\right)+$ farmyard manure (FYM, $1.25 \mathrm{t} \mathrm{ha}^{-1}$ ), and farmyard manure alone $\left(2.5 \mathrm{tha}^{-1}\right)$. These rates were based on previous studies [9] which demonstrated a $40 \%$ increase in maize yields following application of $1.25 \mathrm{t}$ bentonite $\mathrm{ha}^{-1}$. For the legume (green-grams and groundnuts) single superphosphate (SSP) was used instead of DAP. These treatments were applied randomly and replicated five times across the two districts, on $10 \mathrm{~m}$ by $10 \mathrm{~m}$ plot. Individual farmers served as separate replicates. Each farmer selected two of the above five crops. Bentonite, FYM and DAP were surface broadcast and incorporated into the top 10 to $15 \mathrm{~cm}$ soil layer, using a hand rake.

Each crop was planted and managed following the recommended agronomic practices (spacing, planting density, weeding, thinning and spraying). Soil moisture was determined at grain filling stage using an EXTECH Soil moisture meter MO750. The probe was inserted at $20 \mathrm{~cm}$ depth and then $\%$ moisture read directly. At physiological maturity, the number of plants within each harvest area counted and harvested for grain. Soil was sampled $(0-30 \mathrm{~cm})$ at planting and at harvest.

\subsection{Laboratory Analysis}

Samples of the harvested grain were taken to the laboratory, weighed and oven-dried for 3 days at $78^{\circ} \mathrm{C}$ to a constant weight. The loss in weight was used to correct the field weights for grain to obtain yield, expressed on a hectare basis. Soil samples were air-dried and analysed for $\mathrm{pH}$, organic matter $(\mathrm{OM})$, phosphorus, exchangeable $\mathrm{Ca}^{2+}, \mathrm{Mg}^{2+}$, $\mathrm{K}^{+}$, total $\mathrm{N}$ and particle size distribution using standard methods [10]. Seed weight was determined by weighing a known number of seeds (100 seeds for maize, groundnuts and green-grams; 200 seeds for sorghum, and 500 seeds for millet).

\subsection{Economic Analysis}

A benefit: cost ratio analysis was done to assess the economic value of undertaking different treatments. In order to assess the costs and benefits associated with different treatments, a partial budget technique as described by CIMMYT [11] was applied on the yield results. Economic analysis was done using the prevailing market prices for inputs at planting and for outputs at the time of crop harvesting. Costs related to different fertilizers at the time of the experiment were US $\$ 40$ per $50 \mathrm{~kg}$ Calcium Bentonite, US $\$ 48.3$ per $50 \mathrm{~kg}$ DAP, US $\$ 43.3$ per $50 \mathrm{~kg}$ Urea and US $\$ 11$ UGX per Tonne of FYM. Cost of fertilizer application was US \$ 0.0167 per kg. Market prices (3-season averages) for maize, millet, sorghum, green-grams and groundnuts were US $\$ 0.2333,0.4767,0.2267,0.5133$, and 0.9533 per $\mathrm{kg}$, respectively. Gross benefits were calculated as the product between the farm gate price at the time of harvesting and the average adjusted yield per treatment. Net benefits were calculated as the difference between Gross benefits and the Total variable costs. Benefit cost ratio was calculated as Net benefit divided by Total costs. 


\subsection{Data Analysis}

Data for yield were processed using Microsoft Excel and statistically analysed using GenStat package, Version 12.1. Significant differences between means were determined at a 95\% Confidence level and means separated using the Fisher's least significant difference (LSD) procedure. Two means were declared as significantly different when the difference between them was greater than LSD value. A cost-benefit analysis was computed basing on the Total costs that vary (TCV), calculated as the sum of the fertilizer purchase cost and the application cost.

\section{Results}

\subsection{Soil Characterization}

Soil analysis results showed among other things, soils to be predominantly sandy ( 82 to $90 \%$ sand in Katakwi and 76 to $86 \%$ sand in Ngora) (Table 1). Such soils would have poor water retention meaning that crops are likely to suffer from moisture shortage. The soils also had low organic matter
(OM), $\mathrm{P}, \mathrm{Ca}, \mathrm{Mg}, \mathrm{K}$ and CEC. Bentonite on the other hand, had a clay texture and rich in $\mathrm{P}, \mathrm{Ca}, \mathrm{Mg}$ and $\mathrm{K}$, meaning that it could serve as a potential amendment to improve the physical and chemical properties of the infertile, sandy soils in the two districts under study

\subsection{Effect of Bentonite Application on the Grain Yield and Seed Weight of Maize, Finger Millet, Sorghum, Groundnuts and Green Grams}

Maize: Bentonite application at $2.5 \mathrm{t} \mathrm{ha}^{-1}$ resulted in 26 and $51 \%$ increase in maize grain yields during the first and second seasons of 2015, respectively. However, these benefits were not realized during the 2016A season (Table 2). Application of $1.25 \mathrm{t} \mathrm{ha}^{-1}$ bentonite combined with $62.5 \mathrm{~kg}$ $\mathrm{DAP} \mathrm{ha}^{-1}$ (half the recommended rate of $\mathrm{P}$ ) resulted in 53, 59 and $117 \%$ increase in maize grain yields over the control during the first, second and third seasons, respectively. The mean yield across the three seasons was significantly $(\mathrm{P}<0.05)$ higher than the control and translated into $82 \%$ increase in grain yields.

Table 1. Selected characteristics of the Soil, Ca-bentonite and manure used in study

\begin{tabular}{|c|c|c|c|c|c|c|c|c|c|c|c|}
\hline District & $\mathbf{p H}$ & $\mathbf{O M}$ & $\mathbf{P}$ & $\mathbf{C a}$ & Mg & $\mathbf{K}$ & \multirow{2}{*}{$\begin{array}{c}\text { CEC } \\
\begin{array}{c}\mathrm{cmol}(+) / \mathrm{kg} \\
\text { soil }\end{array} \\
\end{array}$} & Sand & Clay & Silt & \multirow[t]{2}{*}{ Textural class } \\
\hline & & $\%$ & \multicolumn{4}{|c|}{$\left(\mathrm{mg} \mathrm{kg}^{-1}\right)$} & & \multicolumn{3}{|c|}{-- } & \\
\hline Katakwi & 6.2 & 1.8 & 5.6 & 746 & 174 & 174 & 10.6 & 85.6 & 9.3 & 5.1 & Loamy sand \\
\hline Ngora & 5.7 & 1.6 & 5.2 & 645 & 150 & 228 & 12.3 & 82.4 & 11.7 & 5.9 & Sandy loam \\
\hline $\begin{array}{c}\text { Critical } \\
\text { values }\end{array}$ & 5.2 & 3 & 45 & 330 & 17 & 55 & & & & & \\
\hline \multicolumn{12}{|c|}{ Selected characteristics for calcium bentonite } \\
\hline Bentonite & 6.9 & 2.7 & 44.1 & 4539 & 1615 & 358 & ND & 7.7 & 78.3 & 14.0 & Clay \\
\hline
\end{tabular}

Table 2. Effect of bentonite application on maize $(10 \mathrm{H})$ grain yield and seed quality

\begin{tabular}{|c|c|c|c|c|c|c|}
\hline & 2015A & 2015B & 2016A & \multicolumn{3}{|c|}{ 3-season average } \\
\hline Treatment & \multicolumn{4}{|c|}{ Grain yield, $\mathrm{kg} \mathrm{ha}^{-1}$} & $\%$ increase & 100 seed wt., $g$ \\
\hline Control & 2016 & 2056 & 2183 & 2096 & & 21.21 \\
\hline Bentonite at $2.5 \mathrm{tha}^{-1}$ & 2558 & 3111 & 1701 & 2339 & 11.6 & 22.19 \\
\hline Bentonite at $1.25 \mathrm{t} \mathrm{ha}^{-1}+62.5 \mathrm{~kg}$ DAP ha ${ }^{-1}$ & 3098 & 3271 & 4735 & 3823 & 82.4 & 26.18 \\
\hline Bentonite at $2.5 \mathrm{tha}^{-1}+, 2.5 \mathrm{t} \mathrm{FYM} \mathrm{ha}{ }^{-1}$ & 1963 & 2545 & 2673 & 2404 & 14.7 & 23.59 \\
\hline $\begin{array}{c}\text { Bentonite at } 1.25 \mathrm{t} \mathrm{ha}^{-1}+1.25 \mathrm{t} \mathrm{FYM} \mathrm{ha}^{-1}+62.5 \\
\mathrm{~kg} \mathrm{DAP} \mathrm{ha}^{-1}\end{array}$ & 2415 & 3196 & 4113 & 3318 & 58.3 & 25.55 \\
\hline $2.5 \mathrm{t} \mathrm{FYM} \mathrm{ha}^{-1}$ & 2009 & 2165 & 2365 & 2196 & 4.8 & 23.06 \\
\hline $\operatorname{LSD}(0.05)$ & 1523.92 & 1587.2 & 3423.2 & 1517.1 & & 4.235 \\
\hline
\end{tabular}


Applying $2.5 \mathrm{t} \mathrm{ha}^{-1}$ bentonite combined with $2.5 \mathrm{t}$ FYM $\mathrm{ha}^{-1}$ resulted in no benefit during the first season, while in the second and third seasons, maize yields increased by 22 to $23 \%$ over the control. A pooled analysis over three seasons translated into $14 \%$ increment, which was not significantly $(\mathrm{P}>0.05)$ different from the control. Combined application of bentonite $\left(1.25 \mathrm{t} \mathrm{ha}^{-1}\right)+$ FYM $\left.1.25 \mathrm{t} \mathrm{ha}^{-1}\right)+$ DAP $(62.5 \mathrm{~kg}$ $\mathrm{ha}^{-1}$ ) resulted in 19\%, 55 and $88 \%$ increase in maize grain yields during the first, second and third season, respectively. This lead to an overall $58 \%$ increase in grain yields over three seasons. On the other hand, application of $2.5 \mathrm{t}$ FYM $\mathrm{ha}^{-1}$ alone did not affect maize yields during any of the three seasons.

A pooled analysis of seed weight over the three seasons indicated that application of bentonite and FYM alone resulted in 4 to $8 \%$ increase in maize 100 -seed weight. Combined application of $1.25 \mathrm{~kg} \mathrm{ha}^{-1}$ bentonite and $62.5 \mathrm{~kg}$ DAP $\mathrm{ha}^{-1}$ improved maize 100 -seed weight by $23 \%$. However, this was not significantly $(\mathrm{P}>0.05)$ different from the control.

Finger millet: Application of $2.5 \mathrm{t} \mathrm{ha}^{-1}$ Ca-bentonite resulted in $20 \%$ increment in grain yields over the three seasons, which was not significantly different from the control (Table 3). On the other hand, applying $2.5 \mathrm{tha}^{-1} \mathrm{FYM}$ increased millet grain yields by $30 \%$ over the control. However, these values were not significantly different from the control. Bentonite combined with DAP raised millet yields by an overall $22 \%$ over the three seasons. Similar results were obtained where bentonite was combined with FYM. Overall, treatments receiving the three amendments combined (Bentonite at $1.25 \mathrm{tha}^{-1}+1.25 \mathrm{t} \mathrm{FYM} \mathrm{ha}^{-1}+62.5$ $\mathrm{kg}$ DAP ha ${ }^{-1}$ ) produced the highest grain yield, recording $42 \%$ values higher than the control over the three seasons. This same treatment also recorded a significantly $(\mathrm{P}<0.05)$ higher millet 500-seed weight over the control.

Sorghum: Analyzed across three seasons, application of $2.5 \mathrm{t} \mathrm{ha}^{-1}$ Ca-bentonite resulted in $14 \%$ increase in sorghum grain yields. Combining bentonite with DAP each at half rates resulted in $26 \%$ increase in yields above the control. This value was almost equivalent to one obtained using bentonite $\left(2.5 \mathrm{t} \mathrm{ha}^{-1}\right)$ and FYM $\left(2.5 \mathrm{t} \mathrm{ha}^{-1}\right)$ (Table 4). Combined application of Bentonite at $1.25 \mathrm{t} \mathrm{ha}^{-1}+1.25 \mathrm{t}$ FYM ha $^{-1}+62.5 \mathrm{~kg}$ DAP ha $^{-1}$ resulted in consistently higher yields compared to the other treatments throughout the three seasons. At this treatment, cumulative grain yield across the three seasons was significantly higher $(\mathrm{P}<0.05)$ than the control. At this treatment, the overall mean grain yield was $42 \%$ higher than the control. This same treatment recorded a significantly $(\mathrm{P}<0.05)$ higher sorghum 200 -seed weight over the control. It is also worth noting that addition of FYM alone led to significantly $(\mathrm{P}<0.05)$ higher 200 -seed weight above the control.

Table 3. Effect of bentonite application on finger millet grain yield and seed weight

\begin{tabular}{|c|c|c|c|c|c|c|}
\hline & 2015A & 2015B & 2016A & \multicolumn{3}{|c|}{ 3-season average } \\
\hline Treatment & \multicolumn{4}{|c|}{ Grain yield, $\mathrm{kg} \mathrm{ha}^{-1}$} & $\%$ increase & 500 seed wt., $g$ \\
\hline Control & 2422 & 800 & 1338 & 1658 & & 1.402 \\
\hline Bentonite at $2.5 \mathrm{t} \mathrm{ha}^{-1}$ & 3419 & 583 & 1776 & 1990 & 20.1 & 1.524 \\
\hline Bentonite at $1.25 \mathrm{t} \mathrm{ha}^{-1}+62.5 \mathrm{~kg}$ DAP ha ${ }^{-1}$ & 3028 & 1306 & 1759 & 2023 & 22.0 & 1.522 \\
\hline Bentonite at $2.5 \mathrm{tha}^{-1}+, 2.5 \mathrm{t} \mathrm{FYM} \mathrm{ha}^{-1}$ & 2294 & 1317 & 1101 & 2033 & 22.6 & 1.517 \\
\hline $\begin{array}{c}\text { Bentonite at } 1.25 \mathrm{tha}^{-1}+1.25 \mathrm{t} \mathrm{FYM} \mathrm{ha}^{-1}+62.5 \mathrm{~kg} \\
\text { DAP ha } \\
\end{array}$ & 3314 & 1294 & 1427 & 2363 & 42.6 & 1.553 \\
\hline $2.5 \mathrm{t} \mathrm{FYM} \mathrm{ha}^{-1}$ & 2815 & 1206 & 1629 & 2157 & 30.1 & 1.457 \\
\hline $\operatorname{LSD}(0.05)$ & 1572.3 & 979.4 & 900.8 & 709.6 & & 0.148 \\
\hline
\end{tabular}

Table 4. Effect of bentonite application on the grain yield and seed weight of sorghum

\begin{tabular}{|c|c|c|c|c|c|c|}
\hline & 2015A & 2015B & 2016A & \multicolumn{3}{|c|}{ 3-season average } \\
\hline Treatment & \multicolumn{4}{|c|}{ Grain yield, $\mathrm{kg} \mathrm{ha}^{-1}$} & $\%$ increase & 200 seed wt., $g$ \\
\hline Control & 1405 & 2073 & 2415 & 2047 & & 2.915 \\
\hline Bentonite at $2.5 \mathrm{t} \mathrm{ha}^{-1}$ & 1752 & 2508 & 2607 & 2347 & 14.7 & 3.401 \\
\hline Bentonite at $1.25 \mathrm{t} \mathrm{ha}^{-1}+62.5 \mathrm{~kg}$ DAP ha ${ }^{-1}$ & 1836 & 2515 & 3091 & 2592 & 26.6 & 3.354 \\
\hline Bentonite at $2.5 \mathrm{tha}^{-1}+, 2.5 \mathrm{t} \mathrm{FYM} \mathrm{ha}^{-1}$ & 1506 & 2750 & 3020 & 2533 & 23.7 & 3.194 \\
\hline $\begin{array}{c}\text { Bentonite at } 1.25 \mathrm{tha}^{-1}+1.25 \mathrm{t} \mathrm{FYM} \mathrm{ha}^{-1}+62.5 \mathrm{~kg} \\
\text { DAP ha }\end{array}$ & 2112 & 3047 & 3319 & 2916 & 42.5 & 3.449 \\
\hline $2.5 \mathrm{t} \mathrm{FYM} \mathrm{ha}^{-1}$ & 1711 & 1734 & 2736 & 2183 & 6.6 & 3.659 \\
\hline $\operatorname{LSD}(0.05)$ & 807.8 & 2326.8 & 1324.2 & 854.7 & & 0.5239 \\
\hline
\end{tabular}


Green-grams: Bentonite application resulted in an overall $17 \%$ increase in green gram yields across the three seasons. Manure application caused a 35\% overall increase in yields above the control, across the three seasons. Combined application of bentonite $\left(2.5 \mathrm{tha}^{-1}\right)$ and FYM (2.5 $\mathrm{t} \mathrm{ha}^{-1}$ ) caused the highest overall increment in grain yields amounting to $42 \%$ above the control (Table 5). Combined application of Bentonite $\left(2.5 \mathrm{t} \mathrm{ha}^{-1}+8.73 \mathrm{~kg} \mathrm{P} \mathrm{ha}^{-1}\right)$ resulted in $32 \%$ increase in yields, while combined application of Bentonite at $1.25 \mathrm{tha}^{-1}+1.25 \mathrm{t} \mathrm{FYM} \mathrm{ha}^{-1}+4.37 \mathrm{~kg} \mathrm{P} \mathrm{ha}^{-1}$ resulted in $38 \%$ higher yields over the control. In general, bentonite application whether pure or combined with DAP and/or manure, had no significant effect on seed weight.

Groundnuts: Bentonite application $\left(2.5 \mathrm{t} \mathrm{ha}^{-1}\right)$ caused a $4.7 \%$ increase in groundnut yields; combining bentonite with FYM increased the yields by $26 \%$. Application of Bentonite at $1.25 \mathrm{t} \mathrm{ha}^{-1}+1.25 \mathrm{t} \mathrm{FYM} \mathrm{ha}^{-1}+4.37 \mathrm{~kg} \mathrm{P} \mathrm{ha}^{-1}$ increased groundnut yields by $22 \%$ over the control (Table 6). However, these mean yield values were not significantly $(\mathrm{P}>0.05)$ different from the control.

\subsection{Effect of Applying Calcium Bentonite on Soil Moisture and Other Soil Properties}

Combined application of Ca-bentonite with DAP or FYM significantly $(\mathrm{P}<0.05)$ improved available soil moisture content (as measured at grain filling stage) over the control
(Table 7). Results also show that within the three, 4-months seasons of this study, bentonite application had no significant $(\mathrm{P}>0.05)$ effect on soil $\mathrm{pH}, \mathrm{OM}, \mathrm{P}, \mathrm{Ca}, \mathrm{Mg}, \mathrm{K}, \mathrm{CEC}$ and percent clay content.

\subsection{Economic Analysis of Bentonite Use in Smallholder Farming}

Economic analysis indicated that application of $2.5 \mathrm{t} \mathrm{ha}^{-1}$ manure to maize was economical when rated against the control for all three seasons. Benefit cost ratios of 3.8, 4.2 and 17.1 were realized in 2015A, 2015B and 2016A seasons, respectively (Table 8 ). Bentonite on maize was profitable following application of Bentonite at $1.25 \mathrm{t} \mathrm{ha}^{-1}+62.5 \mathrm{~kg}$ DAP ha ${ }^{-1}$ and Bentonite at $1.25 \mathrm{tha}^{-1}+1.25 \mathrm{t} \mathrm{ha}^{-1} \mathrm{FYM}+$ $62.5 \mathrm{~kg}$ DAP ha ${ }^{-1}$ for 2016A season. All the other bentonite treatments were not economical across the three seasons.

For finger millet, application of bentonite at $1.25 \mathrm{tha}^{-1}+$ $1.25 \mathrm{tha}^{-1} \mathrm{FYM}+62.5 \mathrm{~kg}^{-1}$ ha DAP was economical during $2015 \mathrm{~A}$ but not in other seasons. Similar results were obtained for sorghum (data not shown). Application of $4.37 \mathrm{~kg} \mathrm{P} \mathrm{ha}^{-1}$ $+1.25 \mathrm{t} \mathrm{ha}^{-1}$ bentonite $+1.25 \mathrm{tha}^{-1}$ FYM on groundnuts resulted into positive benefit/cost ratios in 2016A, and the combined results for the 3 seasons (Table 9). For green-grams, bentonite use was not profitable in all three seasons (data not shown).

Table 5. Effect of bentonite application on the grain yields of green-grams

\begin{tabular}{|c|c|c|c|c|c|c|}
\hline & 2015A & 2015B & 2016A & \multicolumn{3}{|c|}{ 3-season average } \\
\hline Treatment & \multicolumn{4}{|c|}{ Grain yield, $\mathrm{kg} \mathrm{ha}^{-1}$} & $\%$ increase & 100 seed wt., $g$ \\
\hline Control & 496 & 741 & 309 & 500 & & 5.21 \\
\hline Bentonite at $2.5 \mathrm{t} \mathrm{ha}^{-1}$ & 722 & 803 & 331 & 586 & 17.2 & 4.92 \\
\hline Bentonite at $2.5 \mathrm{tha}^{-1}+8.73 \mathrm{~kg} \mathrm{P} \mathrm{ha}^{-1}$ & 685 & 898 & 457 & 661 & 32.2 & 6.00 \\
\hline Bentonite at $2.5 \mathrm{t} \mathrm{ha}^{-1}+2.5 \mathrm{t} \mathrm{FYM} \mathrm{ha}^{-1}$ & 739 & 880 & 560 & 712 & 42.4 & 5.34 \\
\hline $\begin{array}{c}\text { Bentonite at } 1.25 \mathrm{t} \mathrm{ha}^{-1}+1.25 \mathrm{t} \mathrm{FYM} \mathrm{ha}^{-1}+4.37 \mathrm{~kg} \\
\qquad \mathrm{P} \mathrm{ha}^{-1}\end{array}$ & 771 & 780 & 574 & 692 & 38.4 & 5.57 \\
\hline $2.5 \mathrm{t} \mathrm{FYM} \mathrm{ha}^{-1}$ & 618 & 888 & 539 & 675 & 35.0 & 5.69 \\
\hline $\operatorname{LSD}(0.05)$ & 959.3 & 1437 & 300.7 & 517.7 & & 1.116 \\
\hline
\end{tabular}

Table 6. Effect of bentonite application on groundnut yield and seed weight

\begin{tabular}{|c|c|c|c|c|c|c|}
\hline Gnuts & 2015A & 2015B & 2016A & \multicolumn{3}{|c|}{ 3-season average } \\
\hline TRT & \multicolumn{4}{|c|}{ Yield $\left(\mathrm{kg} \mathrm{ha}^{-1}\right)$} & $\%$ increase & 100 seed wgt, $g$ \\
\hline Control & 1275 & 407 & 1561 & 1168 & & 35.0 \\
\hline Bentonite at $2.5 \mathrm{tha}^{-1}$ & 1342 & 323 & 1691 & 1223 & 4.7 & 35.9 \\
\hline Bentonite at $2.5 \mathrm{tha}^{-1}+8.73 \mathrm{~kg} \mathrm{P} \mathrm{ha}{ }^{-1}$ & 1317 & 370 & 1650 & 1210 & 3.6 & 38.2 \\
\hline Bentonite at $2.5 \mathrm{tha}^{-1}+2.5 \mathrm{t} \mathrm{FYM} \mathrm{ha}^{-1}$ & 1375 & 287 & 2254 & 1478 & 26.5 & 35.1 \\
\hline $\begin{array}{c}\text { Bentonite at } 1.25 \mathrm{tha}^{-1}+1.25 \mathrm{t} \mathrm{FYM} \mathrm{ha}^{-1}+4.37 \mathrm{~kg} \\
\mathrm{P} \mathrm{ha}^{-1}\end{array}$ & 1200 & 317 & 2243 & 1433 & 22.7 & 35.6 \\
\hline 2.5 t FYM ha $^{-1}$ & 908 & 332 & 2201 & 1339 & 14.6 & 35.0 \\
\hline $\operatorname{LSD}(0.05)$ & 686.6 & 471.8 & 1064.4 & 538.2 & & 7.88 \\
\hline
\end{tabular}


Table 7. Effect of applying calcium bentonite on soil moisture and other soil properties

\begin{tabular}{|c|c|c|c|c|c|c|c|c|c|}
\hline & Moisture & pH & OM & $\mathbf{P}$ & $\mathbf{C a}$ & Mg & $\mathbf{K}$ & \multirow{2}{*}{$\begin{array}{c}\text { CEC } \\
\mathrm{cmol}_{(+)} \mathrm{kg} \\
\mathrm{soil}^{-1}\end{array}$} & \multirow{2}{*}{$\begin{array}{c}\text { Clay } \\
\%\end{array}$} \\
\hline & $\%$ & & $\%$ & \multicolumn{4}{|c|}{ '-- $\left(\mathrm{mg} \mathrm{kg}^{-1}\right)$ - } & & \\
\hline Initial value & & 5.954 & 1.702 & 4.94 & 722 & 169.6 & 209.5 & 11.54 & 9.84 \\
\hline \multicolumn{10}{|l|}{ Treatments } \\
\hline Control & 9.97 & 5.895 & 1.842 & 6.97 & 632 & 179.2 & 149.6 & 10.51 & 10.54 \\
\hline Bentonite at $2.5 \mathrm{t} \mathrm{ha}^{-1}$ & 9.95 & 5.884 & 1.745 & 6.68 & 641 & 183.3 & 145.1 & 10.47 & 10.65 \\
\hline $\begin{array}{l}\text { Bentonite at } 1.25 \mathrm{t} \mathrm{ha}^{-1}+62.5 \mathrm{~kg} \text { DAP } \\
\mathrm{ha}^{-1}\end{array}$ & 13.98 & 5.859 & 1.696 & 7.55 & 631 & 180.9 & 143.7 & 10.69 & 10.74 \\
\hline Bentonite at $2.5 \mathrm{tha}^{-1}+, 2.5 \mathrm{t} \mathrm{FYM} \mathrm{ha}^{-1}$ & 14.69 & 5.903 & 1.928 & 6.63 & 648 & 186 & 145.2 & 10.30 & 10.80 \\
\hline $\begin{array}{c}\text { Bentonite at } 1.25 \mathrm{tha}^{-1}+1.25 \mathrm{tFYM} \\
\mathrm{ha}^{-1}+62.5 \mathrm{~kg} \mathrm{DAP} \mathrm{ha}^{-1}\end{array}$ & 12.20 & 5.859 & 1.919 & 8.22 & 660 & 186.3 & 144.0 & 10.89 & 10.69 \\
\hline $2.5 \mathrm{t} \mathrm{FYM} \mathrm{ha}^{-1}$ & 10.35 & 5.868 & 1.817 & 6.49 & 628 & 182.9 & 144.2 & 10.54 & 10.72 \\
\hline $\operatorname{LSD}_{(0.05)}$ & 3.60 & 0.176 & 0.271 & 2.014 & 116.5 & 43.65 & 28.87 & 1.833 & 1.955 \\
\hline
\end{tabular}

Table 8. Economic analysis (B/C ratios) for application of Calcium Bentonite and other amendments on maize (Longe 10H)

\begin{tabular}{|c|c|c|c|c|}
\hline Treatment & $2015 \mathrm{~A}$ & 2015B & $2016 \mathrm{~A}$ & $\begin{array}{l}3 \text { SEASON } \\
\text { ANALYSIS }\end{array}$ \\
\hline Control & & - & - & - \\
\hline Bentonite at $2.5 \mathrm{tha}^{-1}$ & $(0.79)$ & $(0.75)$ & $(0.7)$ & $(0.7)$ \\
\hline Bentonite at $1.25 \mathrm{t} \mathrm{ha}^{-1}+62.5 \mathrm{~kg} \mathrm{DAP} \mathrm{ha}^{-1}$ & $(0.52)$ & $(0.50)$ & 0.6 & $(0.2)$ \\
\hline Bentonite at $2.5 \mathrm{tha}^{-1}+, 2.5 \mathrm{t} \mathrm{FYM} \mathrm{ha}^{-1}$ & $(0.84)$ & $(0.80)$ & $(0.5)$ & $(0.7)$ \\
\hline Bentonite at $1.25 \mathrm{t} \mathrm{ha}^{-1}+1.25 \mathrm{t} \mathrm{FYM} \mathrm{ha}^{-1}+62.5 \mathrm{~kg} \mathrm{DAP} \mathrm{ha}^{-1}$ & $(0.64)$ & $(0.52)$ & 0.4 & $(0.3)$ \\
\hline $2.5 \mathrm{t} \mathrm{FYM} \mathrm{ha}^{-1}$ & 3.84 & 4.22 & 17.1 & 6.4 \\
\hline
\end{tabular}

Average maize price $=\mathrm{US} \$ 0.1667$ for $2015 \mathrm{~A} \& \mathrm{~B}, 0.3667$ for $2016 \mathrm{~A}$ and 0.2333 for 3 season analysis

Table 9. Economic analysis (B/C ratio) for application of Calcium Bentonite and other amendments on groundnuts

\begin{tabular}{|c|c|c|c|c|}
\hline Treatment & $2015 \mathrm{~A}$ & 2015B & $2016 \mathrm{~A}$ & $\begin{array}{l}3 \text { SEASON } \\
\text { ANALYSIS }\end{array}$ \\
\hline Control & - & - & - & - \\
\hline Bentonite at $2.5 \mathrm{tha}^{-1}$ & $(0.3)$ & $(0.9)$ & $(0.1)$ & $(0.4)$ \\
\hline Bentonite at $2.5 \mathrm{tha}^{-1}+8.73 \mathrm{~kg} \mathrm{P} \mathrm{ha}^{-1}$ & $(0.4)$ & $(0.8)$ & $(0.2)$ & $(0.4)$ \\
\hline Bentonite at $2.5 \mathrm{tha}^{-1}+2.5 \mathrm{t} \mathrm{FYM} \mathrm{ha}{ }^{-1}$ & $(0.3)$ & $(0.9)$ & 0.1 & $(0.3)$ \\
\hline Bentonite at $1.25 \mathrm{t} \mathrm{ha}^{-1}+1.25 \mathrm{t} \mathrm{FYM} \mathrm{ha}^{-1}+4.37 \mathrm{~kg} \mathrm{P} \mathrm{ha}^{-1}$ & $(0.1)$ & $(0.8)$ & 1.2 & 0.3 \\
\hline $2.5 \mathrm{t} \mathrm{FYM} \mathrm{ha}^{-1}$ & 12.1 & 3.0 & 31.9 & 17.5 \\
\hline
\end{tabular}

Average groundnut price=US $\$ 1.0000$ for $2015 \mathrm{~A}, 0.8333$ for 2015B, 1.0333 for $2016 \mathrm{~A}$ and 0.9533 for 3 season analysis

\section{Discussion}

Results of this study show that averaged over three seasons, application of $2.5 \mathrm{tha}^{-1} \mathrm{Ca}$-bentonite increased the grain yields of maize, finger millet, sorghum, green-grams and groundnuts by $11,20,14,17$ and 4.7 percent, respectively. Bentonite application also increased the seed weight of all five crops. Although the absolute mean values were not significantly different from the control, the increase in grain yields and seed quality represents a potential technology for improving the productivity of degraded sandy soils. In Thailand, application of $1.25 \mathrm{t} \mathrm{ha}^{-1}$ bentonite increased rice yields by $73 \%$ and reduced the risk of crop failure during drought years [12].

The study also shows that the benefits were higher in treatments where bentonite was combined with DAP and/or
FYM. In fact where the three materials were combined, higher yields were obtained with half the recommended rates of either of the materials; this represents a financial saving in terms of input costs hence a more efficient utilization of the scarce fertilizer sources. From Table 7, combined application of bentonite with DAP and/or FYM resulted in higher soil moisture contents over the control. Results from Tables 2, 3, 4,5 , and 6 show that these same treatments also produced higher grain yields and seed weight compared to the control. These results are consistent with those of Berthelsen et al. [13] who concluded that use of bentonite should not preclude use of other indigenous technologies or other locally available materials. In general, the benefits of Ca-bentonite use were mostly observed with cereals (maize, millet and sorghum), which are major staples in the area where the study was conducted, and less so for legumes (groundnut and 
green-grams).

Results also show that within the three, 4-months seasonal durations of this study bentonite application resulted in increased available soil moisture, but had no effect on soil $\mathrm{pH}, \mathrm{OM}, \mathrm{P}, \mathrm{Ca}, \mathrm{Mg}, \mathrm{K}, \mathrm{CEC}$ and percent clay content over the control. In contrast, Manue Arias et al. [7] reported increased $\mathrm{pH}, \mathrm{N}, \mathrm{K}$, and $\mathrm{P}$ contents following bentonite application to an acid soil. Sacchi [14] reported increased soil $\mathrm{CEC}$, exchangeable $\mathrm{Ca}, \mathrm{Mg}, \mathrm{K}$ and plant available water following bentonite application. Studies on the use of bentonite on light textured soils of Australia, China and Thailand, demonstrated that addition of bentonite clay to degraded sandy soils restores their productive capacity within a single season [13]. Noble et al. [15] observed that the benefits persisted over three years following bentonite field application. In Poland, Czaban et al. [16] reported significantly higher organic $\mathrm{C}$ and total $\mathrm{N}$ contents 30 years after treatment with bentonite compared to the control plots.

Results from the economic analysis indicate that use of bentonite alone was not profitable under the prevailing input to produce market prices. However, combining bentonite with DAP and manure improved the profitability for most enterprises, although generally not as profitable as the farmyard manure alone treatment. Profitability depends among other things, on the price of the inputs as well as the produce generated. Although the crops grown in this study were selected by farmers themselves, this experiment has demonstrated that averaged over three seasons, use of $\mathrm{Ca}$ bentonite on maize, millet, sorghum and green-grams under prevailing produce market prices was generally not profitable. Groundnut was an exception to this, since its market price is generally much higher than that of the other four crops.

The question still remains, in view of the high cost of bentonite hence making its use at smallholder level rather uneconomical, how can use of bentonite be made (more) profitable in Uganda and SSA as a whole? The following strategies are proposed to promote its incorporation into the cropping systems: first, crop diversification to higher value crops to offset its high cost. In Thailand for example, farmers having realized the benefits of using $\mathrm{Ca}$-bentonite on forage sorghum, resorted to using $\mathrm{Ca}$-bentonite for growing vegetables, and as a result they earned more on-farm income [16]. Secondly, bentonite could be blended with other materials (e.g. mineral fertilizers, dolomite or organic materials) to make a higher analysis fertilizer. Thirdly, use of bentonite to amend sandy soils in nurseries and greenhouses and reduce water requirements, should be explored. Earlier studies [9] developed appropriate ratios for bentonite and sand mixtures under greenhouse conditions.

However, more research is needed to determine the most cost effective means of application, economic rates under contrasting agro-ecological zones, the residual benefits of bentonite use and the long-term implications of such strategies to enhance the productivity of degraded light textured soils. In Thailand, Berthelsen et al., [13] demonstrated that use of bentonite under farmer field practice resulted in significant financial benefits realized within the first year, with the full cost of purchasing and applying the bentonite being recovered. Studies in Australia showed that bentonite use for sugarcane growing was profitable after 5 years, but was generally un-profitable in the short term or where the ground is re-worked every 3 to 4 seasons.

\section{Conclusions}

Bentonite application improves the soil moisture status of sandy soils resulting in higher grain yields and seed quality of maize, finger millet, sorghum, green-grams and groundnuts. Profitability was higher with groundnuts due to its higher market price compared to the other crops. Considering the high price of bentonite, options such as use on higher value crops, blending with other materials, and use in greenhouses should be explored, to promote its use by smallholder farmers and thereby cope with increasing drought incidences.

\section{Acknowledgements}

The authors would like to thank NARO for provision of funds under Sustainable Land Management (SLM) Project and all other support for this study. We appreciate all the Technicians, Field Assistants and other support staff for their enormous contribution to this work. We also thank all the farmers of Ngora and Katakwi districts who offered their land, time and other resources to make this study a success.

\section{REFERENCES}

[1] Masih I., S. Maskey, F. Mussa and P. Trambauer. 2014. A review of droughts on the African continent: a geospatial and long-term perspective. Hydrol. Earth Syst. Sci., 18, 36353649,2014

[2] Boul, S.W., Southard, R.J., Graham, R.C. and McDaniel, P.A. 2003. Soil genesis and classification (5th ed.). Iowa State Press, Ames, Iowa, pp. 494.

[3] Satje A. and P. Nelson. 2009. Bentonite treatments can improve the nutrient and water holding capacity of sugar cane soils in the wet tropics. Proc. Austr. Soc. Sugar Cane Technol. Vol. 31: 166-176.

[4] Noble, A.D., Gillman, G. P., and Ruaysoongnern, S. 2000. A cation exchange index for assessing degradation of acid soil by further acidification under permanent agriculture in the tropics. European Journal of Soil Science 51: 233-243.

[5] Suzuki S (2004) Verification of freezing point depression method for measuring matric potential of soil water. Soil Science and Plant Nutrition 50, 1277-1280. 
[6] Soda W, Noble AD, Suzuki S, Simmons R, Sindhusen L, Bhuthorndharaj S. 2006. Co-composting of acid waste bentonites and their effects on soil properties and crop biomass. Journal of Environmental Quality 35, 2293-2301.

[7] Manue A. E., E.L. Periago, J.C. Nóvoa-Muñoz, A. Torrado-Agrasar, and J. Simal-Gándara. 2007. Treatment of an Acid Soil with Bentonite Used for Wine Fining: Effects on Soil Properties and the Growth of Lolium multiflorum. http://pubs.acs.org/doi/abs/10.1021/jf070837e

[8] The Republic of Uganda. 2004. Increasing incomes through exports. A Plan for Zonal Agricultural Production, Agro-Processing and Marketing for Uganda.

[9] Semalulu, O., M.K. Magunda, and D.N. Mubiru 2015. Amelioration of sandy soils in drought stricken areas through use of Ca-bentonite. Uganda Journal of Agricultural Sciences (UJAS) 16 (2):175-185. ISSN 1026-0919 (Print); ISSN 2410-6909 (Online).@ National Agricultural Research Organization. http://www.ajol.info/index.php/ujas/index; http://dx.doi.org/10.4314/ujas.v16i2.3

[10] Okalebo, J.R., Gathua, K.W. and Woomer, P.L. 1993. Laboratory methods of soil and plant analysis: A Working Manual. 88p.

[11] CIMMYT (1998). From Agronomic Data to Farmer Recommendations: An economics Training Manual. Completely revised edition. Mexico, D.F.

[12] IWMI. International Water Management Institute. http://www.iwmi.cgiar.org/issues/rainfed-agriculture/summa ry/. Accessed on $14^{\text {th }}$ October 2016.

[13] Berthelsen, S., A.D. Noble, A, S. Ruaysoongnerm, M. Webb,
H. Hengfu, and Y. Jiexiang. 2005. Addition of clay based soil ameliorants to light textured soils to reduce nutrient loss and increase crop productivity. In Hartmann C., N. Chinabut, A. Noble, Y. Niino, T. Vearasilp, A. Polthanee and R. Poss (ed.) Proceedings. Management of Tropical Sandy Soils for Sustainable Agriculture. A holistic approach for sustainable development of problem soils in the tropics. $27^{\text {th }}$ November to $2^{\text {nd }}$ December 2005. pp. 373-382.

https://www.scribd.com/doc/96333043/Management-of-Trop ical-Sandy-Soils-for-Sustainable-Agriculture

[14] Sacchi, A. 2010. Improving the cation retention capacity of Tropical soils using high activity clays. James Cook University, Australia.

[15] Noble AD, Ruaysoongnern S, Berthelsen S, Penning de Vries FWT, Giordano M. 2005. Enhancing the agronomic productivity of degraded soils through clay-based interventions. The International Journal of Agricultural Sustainability 3, 102-113.

[16] Czaban, J., G. Siebilec, E. Czyz and J. Niedzwiecki. 2013. Effect of bentonite addition on sandy soil chemistry in a long-term plot experiment I. Effect on organic C and total N. Pol. J. Environ. Stud. Vol. 22 No. 6 (2013), 1661-1667.

[17] IWMI (International Water Management Institute). 2010. Improving soils and boosting yields in Thailand. Success stories.

http://www.iwmi.cgiar.org/Publications/Success_Stories/ PDF/2010/Issue \%202\%20-\%20Improving_soils_and_boosti ng_yields_in_Thailand.pdf

[18] Sacchi A. 2009. Final report improving the cation retention capacity of cane-growing soils using high activity clays. http://elibrary.sugarresearch.com.au/ 